\title{
Claire Chambers, Britain Through Muslim Eyes. Literary Representations, 1780-1988
}

\section{Claire Gallien}

\section{(2) OpenEdition \\ 1 Journals}

Electronic version

URL: https://journals.openedition.org/ces/4569

DOI: $10.4000 /$ ces.4569

ISSN: 2534-6695

Publisher

SEPC (Société d'études des pays du Commonwealth)

\section{Printed version}

Date of publication: 1 September 2017

Number of pages: 165-167

ISSN: 2270-0633

\section{Electronic reference}

Claire Gallien, "Claire Chambers, Britain Through Muslim Eyes. Literary Representations, 1780-1988",

Commonwealth Essays and Studies [Online], 40.1 | 2017, Online since 02 April 2021, connection on 25 January 2022. URL: http://journals.openedition.org/ces/4569 ; DOI: https://doi.org/10.4000/ces.4569

This text was automatically generated on 25 January 2022.

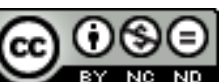

Commonwealth Essays and Studies is licensed under a Licence Creative Commons Attribution - Pas d'Utilisation Commerciale - Pas de Modification 4.0 International. 


\title{
Claire Chambers, Britain Through Muslim Eyes. Literary Representations, 1780-1988
}

\author{
Claire Gallien
}

\section{REFERENCES}

Claire Chambers. Britain Through Muslim Eyes. Literary Representations, 1780-1988. London: Palgrave Macmillan, 2015. 267 p. ISBN (hb): 978-0-230-25259-2. £58.00

1 Britain Through Muslim Eyes is the first of Claire Chambers's two-book project and constitutes a decisive contribution not only to the field of postcolonial studies but also to English literature at large. It offers a detailed analysis of works of non-fiction (travelogues and autobiographies) and fiction written in English or in translation by writers of Muslim heritage who travelled, settled, or were born in Britain and then wrote about this experience, and therefore contributed to the internationalisation of British literature and to forms of British imagination. It begins in the $18^{\text {th }}$ century with the travelogues of Mirza Sheikh I'tesamuddin and Sake Dean Mahomed and ends in 1988 with the publication of The Satanic Verses and the Rushdie Affair, which according to the author, marks a point of departure in the history of British Muslim writing actually more relevant than $9 / 11$ or $7 / 7$. The timespan covered in each of the two books implies an unequal output between the pre- and the post-1988 periods, with the first book covering two centuries while the second (to be published in 2019) examines the past five decades. Yet, this longue durée arrangement is a resounding reminder to readers and postcolonial critics alike that the Muslim literary contribution in Britain cannot be reduced to the present, that it has a history which is entwined with British colonialism and imperialism, and that due acknowledgement of its diversity must be given. Not only does Chambers here touch upon the ideological assumptions undergirding chronological boundaries and the definition of a canon, she also fills a gap in Western literary criticism. Instead of engaging with Islam and the East in British 
literature, Chambers trains her gaze in the opposite direction and ponders on the impact of British encounters on the writings of Muslims and reflects on the critical appreciation of their prose in the British literary landscape.

The book is comprised of a deftly argumented introduction exposing the corpus, methodology, and theory adduced by the author, followed by a first part entitled "Travelling Autobiography," and a second one, "Travelling Fiction." Each part is ordered chronologically and divided into sub-chapters including short biographies and literary analyses of selected works that deal explicitly with Britain. Other criteria include the presence of Muslim characters and the fact that the books have entered the public domain in English (whether originally written in the language or in translation). Chambers is thus able to compare Muslim male and female authors who wrote in Arabic (Ahmad Faris al-Shidyaq, Yahya Hakki, Tayeb Salih), Persian (Mirza Sheikh I'tesamuddin, Mirza Abu Taleb Khan), Urdu (Atiya Fyzee, Maimoona Sultan, Sajjad Zaheer, Qurratulain Hyder, Attia Hosain, Ghulam Abbas, Abdullah Hussein), or directly in English (Sake Dean Mohamed, Najaf Koole Meerza, Aga Khan III, Sir Sultan Muhammad Shah, Tunku Abdul Rahman Putra al-Haj, Zulfikar Ghose, Muhammad Marmaduke Pickthall, Tariq Mehmood, Ahdaf Soueif, Abdulrazaq Gurnah). Given that the writers discussed here are not British born, except for Pickthall, it is not surprising that many of the texts were originally written in Urdu, Arabic, and Persian. However, Chambers only considers the texts translated into English (sometimes with several decades between publication and translation) which restricts the scope of her analysis of Muslim perceptions of Britain and prevents discussions of these perceptions in other-than-English environments.

Chambers proposes an insightful distinction between "England-returned" and "mythof-return" Muslim writers. The latter, roughly until WW2, belonged to the class of elite travellers who stayed in Britain but did not settle permanently (except for Sake Dean Mohamed). The spaces they described were usually London and its cosmopolitan environment, and university towns such as Cambridge and Oxford. They usually wrote in their native languages and had a preference for short stories or novellas. After WW2, the majority of Muslim writers were first-, second-, or third-generation descendants of migrants to the UK. They wrote in English, usually novels, and depicted middle or working class characters and communities belonging to industrial cities in the north where South Asian migrants lived. Chambers thus notices how novelists of the 1980s tend to discuss racial issues pertaining to single communities and how the demographics of labour migration explains why women are generally absent from these novels. Additionally, her comparative perspective occasions illuminating reflections pertaining to the place of religion. In the 1980s, subjects of contention were about race and class relations. "Muslimness," she argues, was taken for granted and Muslim identity rarely discussed as such by the novelists. It is only in contemporary novels that Islam is presented as an "issue." In a sense, for $21^{\text {st }}$-century Muslim writers religion has become an issue, if not the issue, that sometimes overrides but sometimes also intersects and tangles with questions of race, class, and gender.

Even if the book includes works that have for the most part lacked critical attention, the question of selection remains a thorny one. Given her specific blueprint, Chambers had to isolate works which are nonetheless often part of larger productions and are therefore artificially cut off from their textual environments, by which I mean other works by the same writers but also works by other writers in Arabic, Persian, and Urdu, 
and published before or at the same time. Despite the author's stated awareness that the authors she studied in her first book had only a temporary relation with Britain, amongst many, and sometimes much more significant, sites of (re)location, Chambers' readers get little of the salutary trans-national and trans-regional perspective announced. The works are discussed in a British context but not as they were re-read across continents and centuries. For instance, Chambers places the limelight on the fleeting glimpses of Britain that readers catch in Hakki's home-returned novella, Qindil Umm Hashim, which she reads in parallel with Tayeb Salih's Season of Migration to the North and Naipaul's The Enigma of Arrival (1987). However, she does not elaborate on the significance the book may or may not have had amongst Arabic readers since its publication in 1944. Similarly, nothing is said about how these Muslim texts relate to other (post)colonial South-Asian, Black, and Caribbean writings. Finally, her attention to prose means that she discards whole sections of Muslim cultural productions, including poems and films.

Chambers's capacity to read beyond her field of expertise - which is the postcolonial her comprehensive grasp of the secondary literature, and rewarding efforts to synthesize it, must be underlined from the start as quite outstanding. But for those who are already familiar with the literature (Matar, Elmarsafy, Fisher, Teltscher, TavakoliTarghi, Khair, Makdisi), the discussion Chambers has with $18^{\text {th }}$ - and early $19^{\text {th }}$-century Muslim writers is perhaps less original than her disquisitions on post-WW2 literature. She does not work on archival material and does not have the linguistic and philological expertise to do so, and therefore she does not expose new material that would illuminate earlier Muslim writing on Britain. This being said, for those who are not familiar with the literature on which Chambers relies, her discussion remains an excellent starting point. Finally, I should underline that her fine-grained reading of the novels and knowledge of Islamic and Eastern literary traditions allows her to display illuminating developments and I do recommend in particular her reading of Qindil Umm Hashim in the light of Surah al-Nur in the Holy Qur'an (p. 139), her analysis of crosscultural hypotextual feeding in al-Shidyaq's Leg Over Leg (p. 97-106), conceived as a response to Sterne, Swift, Montesquieu and Voltaire, but also Ibn Hajja, Ibn Abi 'Atiq, and Ibn Sari' al-Dila', of "trans-creation" in Qurratulain Hyder (p. 158), and finally her trailblazing developments on "bi-directional movement" (p. 145) in Urdu literature between high-modernism and the dastangoi tradition.

\section{AUTHORS}

\section{CLAIRE GALLIEN}

Claire GALLIEN lectures at the English Department of University Paul Valéry - Montpellier 3 and is member of the IRCL (UMR 5186). Her first book, L'Orient anglais (Voltaire foundation, 2011), deals with the interactions between popular and scholarly cultures of the East in England. Her current book project focuses on translations and reconfigurations of Eastern literary canons by earlymodern British orientalists and contemporary engagements with this canon by writers in English 
and in translation. Her research interests cover issues related to O/orientalism and literary canon formation, contemporary Arab literatures in English / Arabic, postcolonial, decolonial, and comparative literatures and theories, as well as translation studies. 